\title{
Sistem Manajemen Crash Program Campak Pasca Tsunami di Dinas Kesehatan Kota Lhokseumawe
}

\author{
Ismiati*
}

\begin{abstract}
Abstrak
Imunisasi campak adalah program prioritas dalam situasi darurat di pengungsian. Namun, sampai akhir masa tanggap darurat cakupan imunisasi campak di Kota Lhokseumawe tidak mencapai target. Penelitian ini bertujuan mendapatkan gambaran fungsi sistem manajemen crash program campak di Dinas Kesehatan Kota Lhokseumawe tahun 2005, mengidentifikasi hal-hal yang menyebabkan tidak tercapainya target imunisasi dan mengetahui umpan balik dalam pengembangan program imunisasi. Penelitian ini dilakukan dengan rancangan penelitian kualitatif untuk memahami latar belakang yang dialami subjek penelitian dalam melaksanakan fungsi manajemen crash program campak meliputi perencanaan sampai evaluasi serta rencana umpan balik berdasarkan hasil cakupan imunisasi. Pengumpulan data dengan cara wawancara mendalam dan telaah dokumen. Proses perencanaan tidak memadai, penentuan jumlah sasaran berdasarkan proyeksi BPS tidak sesuai dengan kenyataan dilapangan. Pada pelaksanaan imunisasi, jumlah capaian dibawah sasaran yang ditentukan, untuk daerah tertentu pengaruh faktor keamanan yang tidak kondusif. Pencatatan pelaporan, pemantauan dan evaluasi tidak memadai karena jumlah sasaran berbeda dengan sasaran yang telah ditentukan. Umpan balik dilakukan terutama terhadap Puskesmas dengan cakupan rendah dan memantau kasus campak yang mungkin muncul. Gambaran manajemen crash program campak belum memadai terutama pada proses perencanaan jumlah sasaran, sehingga berkaitan pada proses pelaksanaan, pencatatan dan pelaporan, pemantauan dan evaluasi.
\end{abstract}

Kata kunci: Imunisasi campak, crash program campak

\section{Abstract}

Measles immunization is a priority program of emergency in evacuation. Until the end of emergency measles immunization period, Lhokseumawe City could not achieved the target. The objective of study is to obtain the description of management system of measles crash program in Lhokseumawe Health Office in 2005, to identify things that caused low achievement of immunization target and find out feed back in developing immunization program. This research is conducted by qualitative research design to understand background of concerned research subject in doing crash program management function of measles including planning to evaluation and also feed back plan based on immunization result. Data gathering is done by in-depth interview and document study. Planning process is not adequate, target number determined based on BPS projection was not appropriate with reality in field. The immunization coverage was under the target, in certain areas security factor was not conducive. Record keeping, surveillance and evaluation were not adequate because target number differ from determined target. Feed back was done especially to Puskesmas with low coverage and survey measles case that possibly appears. Description of crash program management of measles is not yet adequate, especially in planning process of target number, and it related to implementation process, record and report, surveillance and evaluation.

Key words: Measles immunization, measles crash program 
Gempa bumi dengan kekuatan 8,9 Skala Richter dan gelombang tsunami yang melanda Propinsi Nangroe Aceh Darussalam (NAD) pada akhir tahun 2004 di samping mengakibatkan banyak korban jiwa, juga menyebabkan ratusan ribu penduduk kehilangan tempat tinggal dan terpaksa mengungsi. Penduduk Propinsi NAD sebelum bencana berjumlah 4.204.904 jiwa. Akibat bencana, sampai dengan tanggal 16 Februari 2005 tercatat 217. 133 orang meninggal/hilang atau 5,16\% dari total penduduk. Penduduk yang mengungsi sebanyak 461.125 jiwa. Kondisi sanitasi lingkungan yang buruk ditambah dengan keadaan gizi yang menurun dapat menyebabkan berjangkitnya penyakit menular antara lain diare, ISPA, kulit, campak, malaria dan demam berdarah. ${ }^{1}$

Situasi darurat biasanya akan berakibat pada tingkat kesakitan dan kematian yang tinggi. Faktor-faktor penduduk yang menyebabkan meningkatkan resiko penyakit pada setiap keadaan darurat adalah lingkungan yang tidak sehat, kemiskinan, tingkat kepadatan penduduk yang berlebihan, jumlah dan kualitas air yang rendah, sanitasi lingkungan dan penampungan yang jelek serta pasokan makanan yang kurang.

Salah satu penyebab utama kematian dan kesakitan dikalangan pengungsi adalah campak. ${ }^{2}$ Program prioritas yang perlu segera dilakukan pada keadaan darurat di pengungsian adalah kegiatan imunisasi campak dan pemberian makanan tambahan untuk bayi dan balita, dengan pertimbangan kerentanan golongan umur tersebut. Dalam situasi darurat, vaksinasi campak harus menjadi prioritas yang tertinggi dan dilakukan sedini mungkin, karena campak merupakan suatu penyakit yang paling menular dan dengan virus yang paling kuat. Kepadatan penduduk merupakan lingkungan yang ideal bagi penularan secara cepat dan luas sehingga mengakibatkan morbiditas dan mortalitas yang tinggi terutama pada anakanak. Imunisasi campak diberikan secara serentak kepada bayi mulai berumur 6 bulan hingga 15 tahun tanpa memandang status imunisasi sebelumnya. Selain itu juga dilakukan pemberian vitamin A dengan dosisi yang tepat. ${ }^{3,4}$

Salah satu upaya pencegahan penyakit yang dilakukan sampai 16 Februari 2005 adalah crash program campak, berupa pemberian imunisasi campak terhadap 71.516 anak di lokasi pengungsian atau $79,8 \%$ dari sasaran. Sedangkan bayi dan anak yang mendapat imunisasi campak di seluruh Propinsi NAD adalah 188.580 atau $15,8 \%$ dari total sasaran 1.190 .558 anak. Target yang ditetapkan adalah 90\%. Hasil cakupan imunisasi campak di Kota Lhokseumawe sampai akhir masa tanggap darurat atau tiga bulan pasca tsunami adalah $72,83 \%$.

Pasca-bencana fungsi manajemen belum terlaksana secara optimal akibat infrastruktur kesehatan (gedung, fasilitas perkantoran, sarana komunikasi dan transportasi, sistem informasi dan pembiayaan) yang rusak dan banyak tenaga kesehatan menjadi korban bencana. Di Dinas Kesehatan Provinsi dan Kabupaten/Kota, tenaga kesehatan yang meninggal berjumlah 533 jiwa dari 17 356 tenaga kesehatan yang ada $(3 \%)$. Selain itu, koordinasi penanggulangan bencana lintas sektor dinilai juga sangat lemah.

Penelitian ini dilakukan untuk mengetahui sistem manajemen crash program campak pasca tsunami di Dinas Kesehatan Kota Lhokseumawe. Pemilih lokasi ini dengan pertimbangan wilayahnya yang terkena tsunami dengan cakupan imunisasi crash program campak yang tidak mencapai target. Selain itu, lokasi tersebut mudah dijangkau, lokasi pengungsian, cakupan imunisasi campak rutin sebelumnya rendah. Selain itu, faktor keamanan yang tidak kondusif, sebelum bencana merupakan wilayah NAD yang ditetapkan sebagai Darurat Militer yang selanjutnya menjadi Darurat Sipil. Hal tersebut berdampak pada pembatasan kegiatan program kesehatan di lapangan.

\section{Metode}

Penelitian dengan metode kualitatif ini bertujuan mendapatkan informasi mendalam tentang berbagai faktor yang menjadi latar belakang sistem manajemen crash program campak pasca-tsunami yang lemah. Penelitian ini dilakukan di Dinas Kesehatan Kota Lhokseumawe sampai akhir masa tanggap darurat lemah. Pemilihan informan dibakukan berdasarkan kriteria kecukupan dan kesesuaian. Informan berjumlah delapan orang yang meliputi informan di Dinas Kesehatan dan seluruh Kepala Puskesmas. Sebagian besar data penelitian ini adalah data primer yang berasal dari wawancara mendalam terhadap informan. Data sekunder bersumber dari telaah dokumen crash program campak. Untuk menjamin validitas data dilakukan triangulasi terhadap sumber informasi dengan melakukan cross-check data dengan fakta dari sumber lainnya. Triangulasi dilakukan dengan menggunakan lebih dari satu metode yaitu metode wawancara mendalam dan telaah dokumen. Hasil wawancara mendalam direkam dan dicatat, dibuat transkrip data, dilakukan reduksi data kemudian dibuat matriks berdasarkan isi dan dilakukan verifikasi.

\section{Hasil}

Hasil penelitian meliputi perencanaan, pelaksanaan, koordinasi, pemantauan dan evaluasi terhadap cakupan hasil imunisasi campak. Perencanaan imunisasi crash program campak meliputi perencanaan jumlah sasaran, kebutuhan tenaga, sarana dan logistik, dana serta perencanaan waktu pelaksanaan.

Sasaran imunisasi pada crash program campak berusia 6 bulan sampai 15 tahun menggunakan data proyeksi BPS. Sasaran dilokasi pengungsian adalah sasaran yang didata oleh petugas kesehatan di posko 
kesehatan pengungsian dibantu oleh panitia pengungsian. Di luar pengungsian, pendataan dilakukan menggunakan format khusus dilakukan oleh Bidan Desa yang dibantu oleh petugas Puskesmas serta kader kesehatan. Dalam pelaksanaan sulit mendapatkan data yang akurat pada periode yang telah ditetapkan. Tingkat mobilitas penduduk yang tinggi, sarana transportasi khususnya daerah terpencil sangat rendah, tidak ada dana pengganti transpor petugas pendataan dan keamanan menjadi kendala dalam pendataan sasaran. Sedangkan hasil proyeksi BPS menjadi tidak relevan lagi, karena jumlah penduduk sebelum dan sesudah bencana berbeda jauh.

Tenaga pelaksana imunisasi di lokasi pengungsian adalah paramedis yang bertugas pada posko pengungsian bersama tim Kesehatan Propinsi dan Depkes dibantu tenaga paramedis sukarela lainnya. Tenaga pelaksanaan diluar pengungsian untuk tingkat Puskesmas adalah Bidan di Desa yang dibantu oleh tenaga paramedis Puskesmas dan Pustu setempat. Tiga dari lima, crash program campak Puskesmas dikelola oleh juru immunisasi, karena Kepala Puskesmas ditugaskan memperkuat tim Kesehatan Propinsi. Masih ditemukan pengelola imunisasi yang belum mengikuti pelatihan imunisasi. Dari delapan informan, hanya dua orang yang telah mendapat pelatihan bencana.

Vaksin dan logistik lainnya yang dibutuhkan pada awal pelaksanaan kegiatan dipenuhi dari persediaan yang ada di Dinas Kesehatan Lhokseumawe ditambah dengan logistik yang langsung dibawa oleh tim Kesehatan Propinsi. Untuk kegiatan diluar pengungsian, kebutuhan logistik tersebut dikoordinasikan dengan Dinas Kesehatan Propinsi dan Depkes. Jumlah kebutuhan tersebut disesuaikan dengan jumlah sasaran dengan tambahan $20 \%$ untuk mengantisipasi kekurangan vaksin. Kerusakan salah satu Puskesmas pada saat pelaksanaan imunisasi sudah dapat difungsikan kembali. Perencanaan kebutuhan dana dikoordinasikan dengan Dinas Kesehatan Propinsi dan Depkes. Waktu pelaksanaan imunisasi di lokasi pengungsian direncanakan pada minggu kedua pasca bencana dan diluar pengungsian pada minggu ketujuh sampai berakhirnya masa tanggap darurat yaitu tiga bulan setelah bencana.

Sasaran pelaksanaan imunisasi adalah anak yang berusia 6 bulan sampai 15 tahun tanpa memandang status imunisasi sebelumnya. Pemberian imunisasi disertai vitamin A. Jumlah sasaran yang ditetapkan tidak sesuai dengan hasil proyeksi BPS. Tenaga pelaksana imunisasi adalah paramedis. Di tingkat Puskesmas pengelolaan imunisasi yang dilakukan oleh bukan Kepala Puskesmas motivasi staf dan masyarakatnya kurang optimal. Gangguan keamanan di beberapa daerah berpengaruh terhadap rasa aman petugas lapangan. Logistik dirasakan tersedia mencukupi,tetapi pada pelaksanaan imunisasi, realisasi dana operasional kurang lancar. Dua dari lima Puskesmas menyatakan ketersediaan dana kurang. Meskipun demikian, kegiatan imunisasi terlaksana sesuai dengan jadwal yang telah direncanakan. Program crash program campak dilaksanakan berkoordinasi dengan program lain. Pelaksanaan imunisasi di lokasi pengungsian mendapat dukungan secara lintas sektor, sedangkan diluar pengungsian koordinasi lintas sektor dirasakan kurang berperan.

Pencatatan dan pelaporan dilakukan dengan menggunakan format yang tersedia, hasil pelaksanaan imunisasi dicatat dan direkap oleh jurim Puskesmas selanjutnya dilaporkan ke Dinas Kesehatan setiap hari kegiatan. Sedangkan, hasil kompilasi dari laporan seluruh Puskesmas dikirim ke Depkes melalui faximile karena Dinas Kesehatan Propinsi belum berfungsi akibat mengalami kerusakan berat. Hasil cakupan yang dilaporkan sesuai dengan jumlah sasaran yang berhasil diimunisasi di lapangan. Proses pemantauan dilakukan terhadap pencapaian sasaran, kesiapan petugas, jumlah dan mutu vaksin serta memberi pengarahan dan bimbingan terhadap petugas dan memberi penyuluhan terhadap masyarakat. Pemantauan dilakukan terhadap sasaran yang berbeda dengan jumlah sasaran yang

Tabel 1. Hasil Cakupan Imunisas Crash Program Campak Kota Lhokseumawe sampai Tanggal 28 Maret 2005

\begin{tabular}{llcccc}
\hline \multirow{2}{*}{ Puskesmas } & \multicolumn{2}{c}{ Sasaran } & \multirow{2}{*}{ Cakupan } & \multicolumn{2}{c}{$\%$} \\
\cline { 2 - 3 } \cline { 6 - 7 } & Pro yeksi & Pendataan & & Pro yeksi & Pendataan \\
\hline B Sakti & 14583 & 15977 & 16163 & 110,8 & 101,2 \\
M Dua & 22336 & 17741 & 13597 & 60,87 & 76,64 \\
M Gedong & 7716 & 4406 & 3602 & 46,68 & 81,75 \\
B Mangat & 4289 & 2694 & 1803 & 42,01 & 66,93 \\
B Cut & 1792 & 1802 & 1770 & 98,77 & 98,22 \\
Jumlah & 50.716 & 42620 & 36935 & 72,83 & 86,66 \\
\hline
\end{tabular}

Sumber: Telaah Dokumen Laporan Puskesmas dan P2P 
diproyeksikan BPS.

Evaluasi terlaksana secara tidak maksimal karena walaupun petugas merasa puas terhadap pelaksanaan imunisasi crash program campak namun hasil feed back yang diberikan Dinas Kesehatan menunjukkan prosentase cakupannya masih dibawah target. Hal ini disebabkan oleh sasaran yang ditentukan lebih besar daripada jumlah sasaran yang ada di lapangan. Dari hasil evaluasi, tidak ditemukan kasus campak dilokasi pengungsian dan di luar pengungsian. Dari lima Puskesmas yang ada dalam wilayah Kota Lhokseumawe, dua Puskesmas berhasil mencapai target imunisasi crash program campaknya, sedangkan untuk cakupan immunisasi di lokasi pengungsian mencapai 100\%.

Dari penilaian hasil cakupan imunisasi crash program campak, Kepala Dinas Kesehatan dan pengelola Imunisasi tingkat kabupaten merencanakan melakukan imunisasi campak lanjutan terhadap puskesmas yang belum mencapai target dan terhadap sasaran yang kembali ke desa asal tapi selama mengungsi belum mendapat imunisasi campak. Selain itu juga tetap melakukan pemantauan kejadian penyakit campak.

\section{Pembahasan}

Perencanaan terhadap sasaran dengan pendataan di lokasi dan di luar lokasi pengungsian dilakukan oleh petugas kesehatan yang bertugas dan bidan desa. Karena pada pelaksanaan sulit untuk mendapatkan jumlah data yang akurat dalam waktu yang singkat, selain itu ditemukan perbedaan jumlah penduduk sebelum dan sesudah bencana yang menyolok. Oleh sebab itu, diambil kebijaksanaan menggunakan data sasaran dengan melakukan proyeksi. Untuk sasaran imunisasi crash program campak usia dari 6 bulan sampai 15 tahun ditentukan proyeksinya adalah $30 \%$ dari jumlah penduduk, ini sesuai dengan proyeksi BP. Pengecualian di berikan di lokasi penampungan pengungsi, sasaran ditentukan berdasarkan hasil pendataan langsung. Usia sasaran ini sesuai dengan ketentuan WHO, The Sphere Project dan Depkes. Jumlah sasaran hasil proyeksi BPS ini tidak sesuai dengan jumlah sasaran yang sesungguhnya.

Memasuki bulan kedua pasca bencana hampir semua petugas kesehatan telah melakukan tugasnya seperti biasa. Hasil penelitian ini berbeda dengan hasil Kajian Asesmen Depkes yang menyatakan pasca tsunami manajemen kesehatan tidak optimal disebabkan petugas kesehatan masih trauma sehingga belum bisa bekerja seperti biasa. Untuk Puskesmas yang pelaksanaan crash program campak dikoordinir oleh Jurim Puskesmas, dirasakan beban kerja yang bertambah karena selain melakukan tugas sebagai jurim, ia juga bertanggung jawab terhadap pelaksanaan dan keberhasilan program imunisasi campak diwilayahnya.
Perencanaan kebutuhan sarana, logistik dan dana dikoordinasikan dengan Dinas Kesehatan Propinsi dan difasilitasi oleh Depkes, karena bencana tsunami di NAD ditetapkan sebagai bencana Nasional dan sesuai dengan PP No. 25 tahun 2000 tentang Kewenangan Pemerintah dan Kewenangan Propinsi sebagai Daerah Otonom sehingga pelaksana wewenang Pemerintah Daerah diambil alih oleh Pusat.

Dari hasil wawancara dan penelusuran dokumen di semua Puskesmas, diketahui bahwa semua Puskesmas menyusun jadwal pelaksanaan ke desa-desa dan sekolahsekolah menurut tanggal dan petugas vaksinatornya. Imunisasi di lokasi penampungan pengungsi dilakukan pada minggu kedua berdasarkan sasaran yang telah di data sebelumnya yaitu anak yang berusia 6 bulan sampai 15 tahun tanpa memandang status imunisasi sebelumnya. Demikian juga di luar pengungsian, imunisasi diberikan kepada sasaran yang berumur 6 bulan sampai 15 tahun dengan tanpa memandang status imunisasinya yang berada di Desa dan Sekolah dari TK sampai SMP. Pelaksanaan terhadap usia sasaran ini sesuai dengan yang ditentukan oleh WHO, The Sphere Project dan Depkes. Jumlah sasaran yang ada tidak sesuai dengan proyeksi BPS.

Tenaga pelaksana vaksinasi di desa dan sekolah adalah bidan desa dan tenaga perawat atau bidan Puskesmas. Hal tersebut sesuai dengan standar tenaga imunisasi dalam Pedoman Pelaksanaan Program Imunisasi oleh Depkes. Dalam proses penggerakan dan pelaksanaan program kesehatan, Kepala Puskesmas terlibat secara langsung memberi andil yang cukup besar dalam meningkatkan keberhasilan program. Kebersamaan yang dibangun dapat memberi motivasi tersendiri bagi setiap staf. Hal ini sesuai dengan penelitian Adiono, ${ }^{4}$ Alexy ${ }^{5}$ dan Nadeak, ${ }^{6}$ yang menyatakan bahwa ada hubungan yang bermakna antara kepemimpinan dengan motivasi dan kinerja perawat. Peran lintas sektor diperlukan untuk penggerakan masyarakat dan mendukung keamanan dalam pelaksanaan imunisasi di daerah rawan konflik agar adanya rasanya aman bagi petugas yang melaksanakan tugas dilapangan.

Ketersediaan sarana dan logistik dirasakan cukup sedangkan ketersediaan dana sebagian Puskesmas menyatakan kurang. Realisasi dana kurang lancar. Waktu pelaksanaan sesuai dengan ketetapan yaitu sampai berakhirnya masa tanggap darurat. Kerja sama lintas program berjalan dengan baik. Hal tersebut meningkatkan efektifitas dan efisiensi serta memudahkan koordinasi antara program. Dinas Kesehatan melaksanakan program kesehatan di pengungsian bersama-sama. Dilokasi pengungsian, dukungan lintas sektor dirasakan baik, tetapi di desa-desa, lintas sektor dirasakan kurang berperan. Dari satu sisi hasil penelitian ini sesuai dengan hasil kajian asesmen yang dilakukan Depkes yang menyebutkan 
koordinasi dengan lintas sektor pada pasca tsunami lemah sehingga mempengaruhi manajemen kesehatan. Namun, di sisi lain tidak sesuai karena dilokasi pengungsian ternyata koordinasi berjalan secara sangat baik. Peran lintas sektor diperlukan dalam rangka meningkatkan penggerakan masyarakat dan mengantisipasi gangguan keamanan.

Sistim pencatatan dan pelaporan kegiatan imunisasi dilakukan mulai dari unit pelaksanaan di pengungsian, desa dan sekolah. Secara umum sistim pelaporan sudah cukup baik dan tidak ada kendala dalam pembuatan pelaporan maupun pengiriman dari Puskesmas ke Dinas Kesehatan. Hasil kompilasi laporan dari semua Puskesmas dikirim langsung ke Depkes, tidak melalui Propinsi karena saat itu aktifitas kantor Dinas Kesehatan Propinsi belum berjalan baik. Pencapaian yang dilaporkan adalah hasil cakupan dibandingkan dengan sasaran berdasarkan proyeksi BPS, sehingga persentasenya lebih rendah bila dibandingkan dengan sasaran berdasarkan pendataan.

Di tingkat Dinas kesehatan, pemantauan dilakukan dengan membentuk tim yang turun ke lapangan secara bergiliran. Pada saat pemantauan dilakukan pengawasan terhadap sasaran, kesiapan petugas, proses pelaksanaan, kecukupan vaksin dan logistik lainnya, potensi vaksin, mengetahui dan mengatasi hambatan yang dialami serta memberi penyuluhan. Pembinaan dilakukan terhadap Puskesmas terutama yang cakupannya sangat rendah. Proses pemantauan tidak maksimal karena jumlah sasaran yang dipantau berbeda dari hasil proyeksi BPS. Pemantauan biasanya dilakukan pada saat tim Dinas Kesehatan berkunjungan ke lokasi pengungsian dan bertepatan dengan jadwal pemberian imunisasi di desa atau di sekolah wilayah yang bersangkutan. Bila dibandingkan dengan target yang telah ditentukan, hasil pelaksanaan imunisasi crash program campak pascatsunami di wilayah kota Lhokseumawe belum mencapai target yang diharapkan. Hal ini kemungkinan disebabkan karena target yang ditentukan tidak sesuai dengan kondisi yang sebenarnya sebab target yang ditentukan adalah hasil dari proyeksi penduduk, masih banyaknya penduduk yang keluar dari desa asalnya, masih adanya faktor gangguan keamanan, dan kurang mampunya jurim menggantikan fungsi Kepala Puskesmas dalam menggerakkan staf dan masyarakat.

Walaupun demikian, berdasarkan evaluasi dan pemantauan yang dilakukan secara terus-menerus, sampai sembilan bulan pasca-tsunami, di wilayah Kota Lhokseumawe, tidak ditemukan kasus campak. Dana untuk melakukan evaluasi tidak tersedia secara khusus. Menurut Azwar, ${ }^{7}$ kegiatan evaluasi atau penilaian adalah untuk mencari tiga jawaban, yaitu apakah masalah yang ada telah berhasil diatasi ?, apakah tujuan yang dirumuskan telah berhasil dicapai ? dan bagaimana aspek efektifitas dan efisiensi program yang telah dilaksanakan tersebut. Peranan evaluasi ini sangat penting, paling tidak dapat membantu dalam pengambilan keputusan.

Dari lima Puskesmas hanya dua Puskesmas yang hasil pelaksanaan crash program campaknya mencapai target. Target yang ditentukan adalah minimal $90 \%$ dari sasaran yang berumur 6 bulan sampai 15 tahun. Menurut WHO cakupan yang diperlukan untuk mencegah penyebaran penyakit campak secara efektif adalah 90-95\%. ${ }^{8}$ Secara keseluruhan sampai berakhirnya masa tanggap darurat atau tiga bulan pascatsunami cakupan imunisasi crash program campak belum mencapai target yang diharapkan, yaitu hanya $72,83 \%$.

Rencana umpan balik yang dilakukan oleh Dinas Kesehatan adalah melakukan imunisasi campak lanjutan terhadap Puskesmas-puskesmas yang belum mencapai target dan terhadap sasaran yang kembali lagi ke desa asalnya tapi belum mendapat imunisasi campak, disamping tetap memantau kejadian penyakit campak yang mungkin muncul. Rencana umpan balik ini dilakukan melalui supervisi ulang dan pembinaan lanjutan terhadap program imunisasi, khususnya imunisasi campak dan pembinaan terhadap petugas.

\section{Kesimpulan}

Untuk sasaran di luar lokasi pengungsian, jumlah sasaran menggunakan proyeksi 30\% dari jumlah setelah bencana bukan merupakan jumlah sasaran yang sesungguhnya. Tenaga dalam pelaksanaan crash program campak cukup memadai karena jarak antara waktu bencana dan pelaksanaan imunisasi cukup lama sehingga semangat bekerja petugas sudah pulih. Keberadaan Kepala Puskesmas dalam pelaksanaan program sangat penting sebagai motivator bagi penggerakan petugas dan masyarakat.

Koordinasi lintas program sudah berjalan dengan baik, sehingga dapat meningkatkan efektifitas dan efisiensi. Koordinasi lintas sektor dilokasi pengungsian lebih mudah dilakukan dibandingkan dengan kegiatan di luar pengungsian. Jumlah cakupan yang dilaporkan adalah hasil imunisasi campak terhadap sasaran yang ada. Dalam meningkatkan efektifitas dan efisiensi, pemantauan dilakukan bersama lintas program dan lintas sektor. Jumlah sasaran yang dipantau tidak sesuai dengan telah ditentukan.

Sampai berakhirnya masa tanggap-darurat yaitu tiga bulan pascabencana, cakupan imunisasi campak di wilayah Kota Lhokseumawe tidak mencapai target yang diharapkan dan sampai sembilan bulan pascabencana tidak ditemukan kasus penyakit campak. Rencana umpan balik yang dilakukan Dinas Kesehatan adalah melakukan imunisasi campak lanjutan terhadap 
Puskesmas yang cakupan imunisasi campaknya rendah dan terhadap sasaran yang kembali lagi kedesanya sementara belum mendapat imunisasi campak, disamping tetap memantau kasus penyakit campak yang mungkin muncul.

\section{Daftar Pustaka}

1. Depkes RI, 2004. Campak di Indonesia. Info Penyakit Menular. Ditjen PPM\&PL-Depkes. Desember 2004.

2. WHO, 2001. Buku Pegangan Kedaruratan Komisi Tinggi PBB untuk Urusan Pengungsi. Geneva.

3. The Sphere Project, 2004 Humanitarian Charter and Minimum Standard in Disarter Response
4. Adiono,S. 2002. Analisis Kepemimpinan yang Mendorong Iklim Kerja dan Motivasi serta dampaknya Terhadap Kinerja Perawat di Rumah Sakit Sekota Palu. Tesis PS FKM-UI. Jakarta.

5. Alexy, Oktoman. 2004. Hubungan Karakteristik Individu, Motivasi dan kepemimpinan dengan Kinerja Tenaga Perawatan di Rumah sakit Polisi Pusat RS Sukanto Jakarta Tahun 2004. PS KARS-UI. Jakarta.

6. Nadeak, DK. 2004. Analisis Pelaksanaan Pengelolaan Lingkungan Rumah Sakit di Wilayah Kodya Jakarta Timur. PS FKM-UI. Jakarta

7. Azwar,A. 1996. Pengantar Administrasi Kesehatan. PT Binarupa Aksara. Yakarta

8. Aktif dengan UNICEF dalam tahap kedua kampanye imunisasi campak. http://www3.kalbefarma.com/index.php 